\title{
A local scour prediction method for pile caps in complex piers
}

\begin{abstract}
The outcomes of an experimental study on local scour at a pile cap are presented. Experiments were conducted with the approaching flow having an undisturbed flow depth and a threshold flow velocity. The main variables investigated were pile cap dimensions and location relative to the streambed. According to the rate of change in scour depth, the scour at a pile cap for different cap levels was divided into four cases. Equations for a correction factor for these four cases are derived. The correction factor $\mathrm{Kc}$ has the effect of reducing the scour depth from a corresponding full-depth pier of the same width as the pile cap. A new methodology is presented to estimate local scour depth at a pile cap as a component of a complex pier. The proposed method was evaluated with the results from this experimental study and historical measurements. The proposed method, which corresponds closely to the observations, can be used to predict local scour at a pile cap as a component of a complex pier in the superposition method. It is also applicable to the prediction of local scour due to a caisson being sunk onto a mobile bed in a current.
\end{abstract}

Keyword: Bridges; Models (physical); Piles \& piling 